\title{
The worldwide impact of Donati's comet on art and society in the mid-19th century
}

\author{
Antonella Gasperini ${ }^{1}$, Daniele Galli ${ }^{1}$ and Laura Nenzi ${ }^{2}$ \\ ${ }^{1}$ INAF, Osservatorio Astrofisico di Arcetri, Largo Enrico Fermi 5, 50125 Firenze, Italy \\ email: gasperi@arcetri.astro.it, galli@arcetri.astro.it \\ ${ }^{2}$ Department of History, University of Tennessee, \\ 915 Volunteer Blvd., Knoxville, TN 37996-4065, USA \\ email: Inenzi@utk.edu
}

\begin{abstract}
Donati's comet was one of the most spectacular astronomical events of the nineteenth century. Its extended sword-like tail was a spectacular sight that inspired several literary and artistic representations. Traces of Donati's comet are found in popular magazines, children's books, collection cards, and household objects through the beginning of the twentieth century.
\end{abstract}

Keywords. Donati's comet, 19th century literature and art

\section{Introduction}

Donati's comet was discovered in Florence on June 2, 1858. It became visible to the naked eye in the northern and southern hemispheres between September 1858 and March 1859. Its gracefully curved tail, which extended almost 40 degrees in the southwestern sky, made a great visual impact and inspired several pictorial (paintings, watercolours, sketches) and poetic (lyrical and satirical) representations, especially in Great Britain and France. In the Eastern world, the influence of Donati's comet on contemporary society is particularly significant in Siam and Japan. context. This contribution outlines the relations and interconnections between a scientific discovery, the artistic movements of the period, and the different social environments in a worldwide context.

\section{The discoverer, Giovanni Battista Donati}

Giovanni Battista Donati was born in Pisa in 1826 and studied physics and mathematics at the local University under the guidance of O. F. Mossotti and C. Matteucci. At the time of the discovery, Donati worked as a professor of astronomy at the Regio Istituto di Studi Superiori (which later became the University of Florence) and as assistant to G. B. Amici, the renowned instrument-maker, astronomer, naturalist, and then-Director of the Museo di Storia Naturale (Museum of Natural History) in Florence. Good luck struck Donati at 10 PM on June 2, 1858, when he discovered a faint nebulosity in the constellation Leo, which would become "l'une des plus belles comètes du XIXème siècle" (C. Flammarion). Thus, "from being a comparatevely obscure observer, Donati found himself suddenly the astronomical hero of the day, for his brilliant comet not only formed an interesting subject for intelligent study [...] but it also created for a time a lively taste for astronomy among all classes of the community" $\dagger$.

$\dagger$ from Donati's obituary in MNRAS, 34, 153 (1874) 


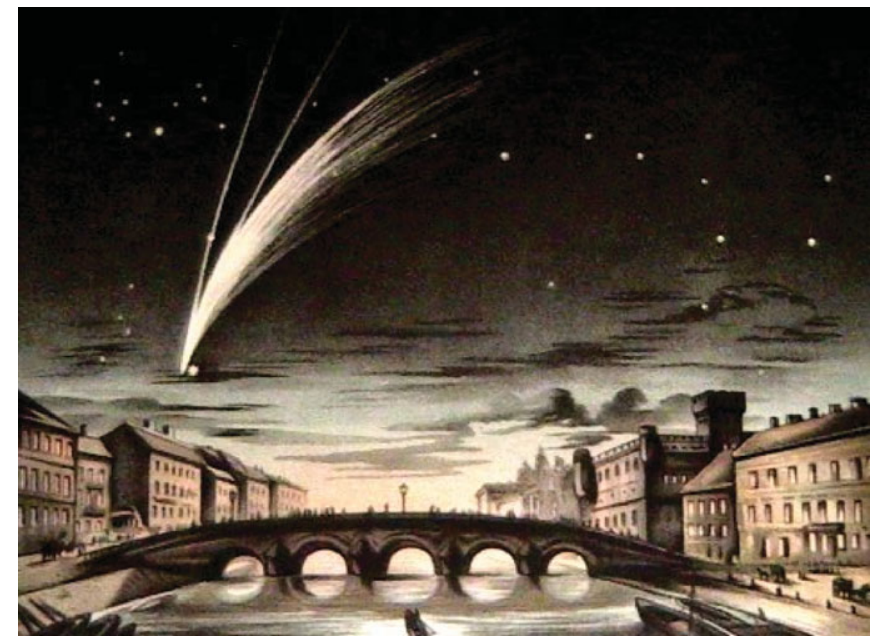

Figure 1. Donati's comet over an imaginary city landscape, from a late 19th century encyclopedia of astronomy (Weiss 1888). Note the constellations of Ursa Major, Corona Borealis and the bright star Arcturus.

A pioneer of spectroscopic studies, Donati was the first to suggest a classification of the stars based on their spectral properties (in 1862), and the first to measure the spectrum of a comet (in 1864). His observations and interpretations of stellar spectra were the first astrophysical studies performed in Italy and in the world. He devoted the last years of his life to the study of aurorae and to the construction of a new astronomical observatory on the hills of Arcetri. The observatory was inaugurated one year before his premature death by cholera in 1873 .

\section{The great comet of $\mathbf{1 8 5 8}$}

Donati's (officially C/1858 L1, formerly $1858 \mathrm{VI}$ ) was the fifth comet to be discovered in 1858, and the fourth discovered by Donati (he would discover two more in 1864). In August, as it approached the Sun, the comet grew rapidly in brightness and developed a tail that at the end of September had reached a length of 30 degrees. After passing perihelion on September 30th, the comet became a truly impressive sight by the first days of October, when its head transited near the bright star Arcturus. The length of its elegantly curved tail reached about 40 degrees, with a maximum width of about 10 degrees. It was the first comet to be photographed: on September 27th by the English artist Usherwood with a portrait camera, and the next day by astronomer G. P. Bond of Harvard College Observatory with a telescope (Pasachoff, Olson \& Hazen 1996).

The comet then begun to steadily fade and became visible in the southern hemisphere, where it was observed by T. Maclear and W. Mann at the Royal Observatory of the Cape of Good Hope, South Africa, and was last seen by C. W. Moesta at the National Observatory of Santiago, Chile, in March 1859. The orbit computed by G. W. Hill in 1865 resulted in a period of about $1950 \mathrm{yr}$.

Scientific accounts of observations of Donati's comet are too numerous to be listed here: see Kronk (2003). We only mention the famous monographic study of G. P. Bond (1862), beautifully illustrated with 51 engravings of the telescopic and naked-eye appearance of the head and tail of the Comet; this work made Bond the first American to be awarded the gold medal of the Royal Astronomical Society. 


\section{The coverage in the press and the impact on the literary world}

Donati's comet, a true media event of its time, was very much in the public news in September-October of 1858. On October 29th, 1858, the Director of the Observatoire de Paris, Joseph Urbain LeVerrier, wrote to Donati: "Since the comet has become visible to the naked eye, a crowd of journalists-astronomers has gathered here in Paris, publishing the most fanciful observations and the most extravagant theories. We have then been forced to keep a reserved attitude, compatible with serious science" $\dagger$.

Several accounts of Donati's comet in newspapers and popular magazines bespeak the widespread fascination and excitement generated by this astronomical event on the European society of the mid-nineteenth century. The Illustrated London News in Britain, Le Monde Illustré in France, Harper's Weekly and The New York Times in the USA, played an important role in disseminating astronomical information about the comet, while satyrical magazines like Le Charivari and The Punch published humourous accounts of the comet-frenzy that swept across most of Britain and France. The comet left significant marks in the works or the personal diaries of writers like Charles Dickens (Dickens 1858) Nathaniel Hawthorne (Hawthorne 1884) and Jules Verne (Verne 1877).

The appearance of Donati's comet left a vivid trace in several poetical compositions of different character (and quality). Some poets, like the reverend Alexander J. D. D'Orsey in The great comet of 1858 were struck by the awesome view of the celestial object:

Then came the climax! Oh that glorious hour!

The mighty Comet in its pride of power!

No sight like that had ever met my gaze!

No sight like that will living man amaze!

Beautiful vision! Feathery, graceful, bright,

A starry diamond in a veil of light!

Others, like Henri Calland in La comète de 1858, were intrigued by the mystery about the constitution and the origin of the comet,

Mystérieux navire au sillage de flamme,

Tu glisse dans les airs sans boussole et sans rame:

$\cdots$

Oh! parmi les mortels, qui nous fera connaître

La nature, le fond, l'essence de ton être?

Chacun, sur ton passage accourant ici-bas,

Te regarde, t'admire, et ne te comprend pas.

Sometimes the comet was an inspiration for religious sentiments, especially in poetic compositions published in ladies' journals or family's magazines. To Nellie W. Steele, in the poem To Donati's comet of 1858, published in Ladies' Repository of Dec. 1858, the comet is a manifestation of the glory and will of God:

A flaming beacon for angelic hands-

A wandering torch-light gleaming in the

Rayless void, and brightening up its dark,

Untraversed fields - at his behest who speaks -

And light fulfills his word.

...

But still I know, thou flaming orb of light,

My Father's hand hath formed thee - his power

Upholds, his word sustains, his will directs

Thy flying path.

$\dagger$ Letter in the Historical Archive of the Arcetri Observatory, Florence. 


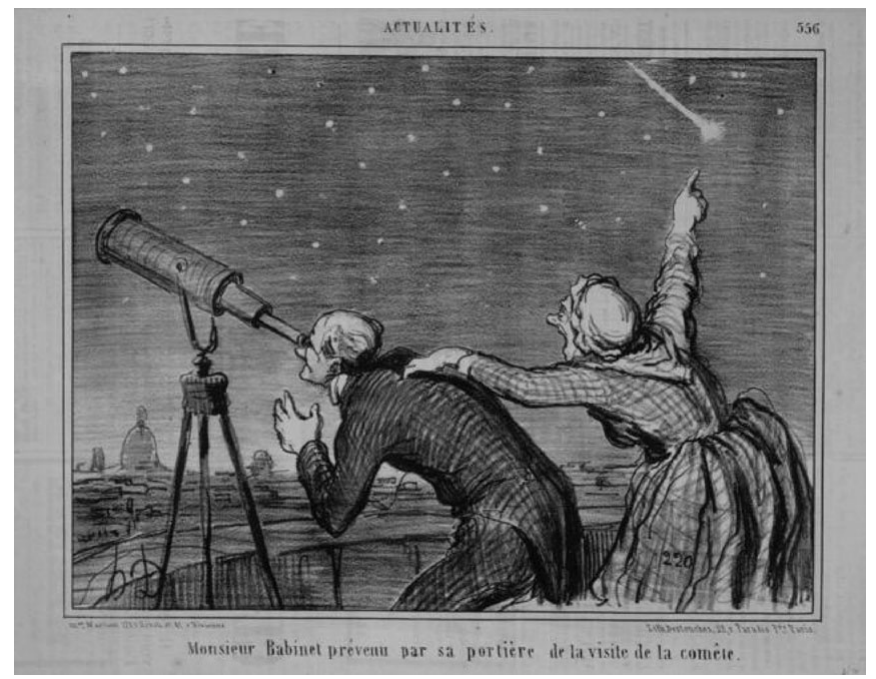

Figure 2. Example of humorous illustration of Donati's comet: M. Babinet alerted by his maid to the passage of the comet, lithograph by H.-V. Daumier appeared in Le Charivari, 22 September 1858.

The motives of the passing of time and the impermanence of life, probably also influenced by news of Donati's comet long period, are at the center of an intense poem by Thomas Hardy, The comet at Yell'ham, published in 1902 but inspired by his memories of Donati's comet (Ray 2002):

It bends far over Yell'ham Plain,

And we, from Yell'ham Height,

Stand and regard its fiery train,

So soon to swim from sight.

It will return long years hence, when

As now its strange swift shine

Will fall on Yell'ham; but not then

On that sweet form of thine.

\section{Paintings of Donati's comet}

Many British artists, fascinated by the magnificence of Donati's comet, attempted to reproduce it in paintings and watercolours that placed the celestial object either in a realistic or in a symbolic landscape. The pivotal study by Olson \& Pasachoff (1998) outlines the different points of view of the artists with respect to this astronomical event. For some, the comet was a secondary element in the landscape, the aim of the work being a reflection on nature, time, and the universe. This is the case for two watercolours by William Turner of Oxford (Yale Center for British Art, Paul Mellon Collection, New Haven, CT) or for the painting Pegwell Bay: A recollection of 5th October 1858 by William Dyce (Tate Gallery, London). Dyce's painting, one of the most memorable PreRaphaelite landscapes, is a meditation on man's place in nature, where the abyss of space (the comet in the sky) and time (the geological stratifications of the cliffs) seem to haunt the small group of people on the beach. Conversely, some artists represented the comet with great astronomical accuracy focusing their attention on specific characteristics like the shape of the tail or the surrounding stars. For example, Samuel Palmer's painting 


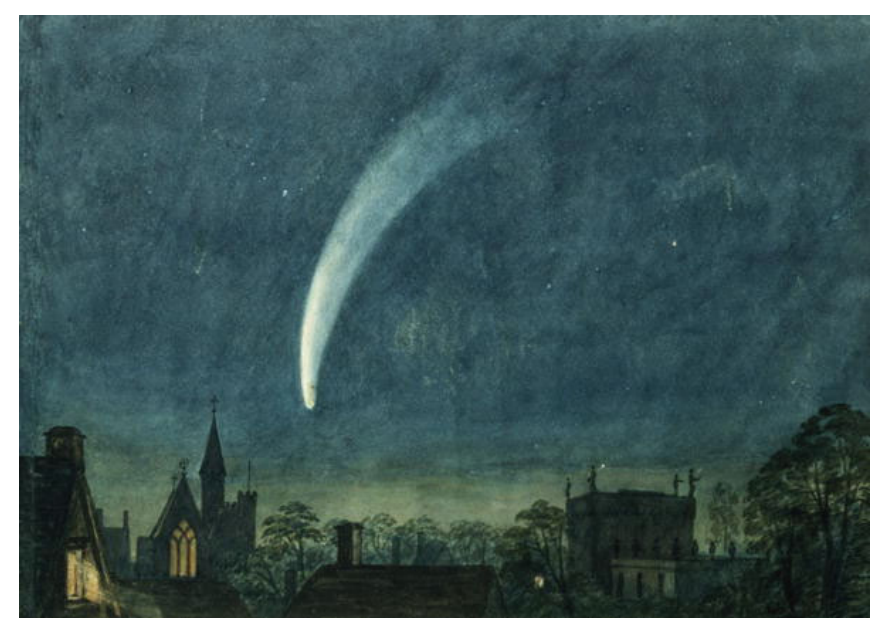

Figure 3. Anonymous: Victorian transparency of Donati's comet over Balliol and Trinity College, Oxford, near the star Arcturus, 5 October 1858, watercolour (Maas Gallery, London).

Donati's comet of 1858 over Dartmoor (priv. coll., London) shows with great accuracy the stars Arcturus, $\epsilon, \delta$ and $\eta$ Bootis, and two stars of the constellation Corona Borealis.

\section{Donati's comet in the world}

A time of great geographical expeditions, the mid-nineteenth century thrived with explorers, travelers, and adventurers. Reports of Donati's comets are found in the diaries and letters of famous and obscure explorers alike, of military officers, and of fortune seekers in the most disparate corners of the world. David Livingstone observed Donati's comet during his stay in Mozambique (he noted in his diary: Observed a comet this evening. It is a fine one, the tail a little bent) and described the natives' reactions to the sight; James Hector, a member of the Palliser expedition in Canada, observed the comet on 11 September; Captain McClintock, on board of the ship Fox travelling towards the Arctic Circle, observed the comet on 14 September; William Hayes Hilton, a soldier, miner, rancher and stock broker in the southern US states, produced a lively sketch of Donati's comet over a stagecoach in Arizona; King Mongkut of Siam, a learned and mathematically proficient monarch able to perform astronomical calculations, observed Donati's comet and tried to eradicate his people's superstitious fear of comets and eclipses with public speeches and interventions.

The great comet of 1858 was observed in Japan as well. It is mentioned in a variety of historical records, ranging from official reports to private diaries, from literary works to printed broadsheets akin to modern day newspapers. Men and women, samurai and merchants, priests and astronomers all left records of the 1858 comet. It goes without saying that no such document referred to it as "Donati's" - it was generally called the hōkiboshi (comet, lit. "broom star" because of its sweeping tail).

The reactions to the appearance of the "broom star" in Japan varied greatly but can be broadly categorized into two main groups. One group of observers took an empirical, even scientific approach to it, and left descriptions that simply record the date and time of observation, the direction of movement, the estimated length of the tail, and other such technical aspects. Many others, however, interpreted the comet as a portent. This was certainly not new, but in the specific case of the 1858 comet it was particularly meaningful and justified by historical circumstances, as the star had arrived at an especially critical 
time for Japan: the Tokugawa government had just signed controversial treaties with foreign powers, triggering discontent and fears of capitulation to the "barbarians," the shogun had died leaving no designated successor, rice riots had broken out in various regions, and a virulent cholera epidemic was sweeping across the country. Amidst such turmoil the comet seemed like a baleful omen of further disaster, portending political, economic, or social catastrophe. In many of these records the comet is referred to as the "war star" or the "calamity star". Not everyone, however, took it as a negative sign: other observers interpreted the hōkiboshi as a harbinger of welcome change, and renamed the "star of the year of abundance" (hoping it would indicate a plentiful harvest) or even the "world renewal star".

\section{Conclusions}

Donati's comet appeared right at the dawn of modern astrophysics, when techniques like spectroscopy and astrophotography were being applied for the first time to the study of celestial objects. This was also a time of strong and widespread interest in scientific discoveries and in the popularization of science. Traces of the comet's passage and of its impact on Victorian society are found in books, illustrated magazines, diaries, and letters. Its unique shape was represented in engravings, watercolours, and paintings ranging from naturalism to symbolism. Donati's comet was not only an astronomical phenomenon of worldwide resonance but also a media event of its day and age, celebrated by journalists, artists, and scientists alike.

\section{References}

Bond, G. P. 1862, Annals of Harvard College Observatory, 3, 1

Dickens, C. 1858, Chips from the comet, in Household Words, November

Hawthorne, J. 1884, Nathaniel Hawthorne and his wife (Boston: The Riverside Press), Vol. II, Chapt. 5

Kronk, G. W. 2003, Cometography: a catalog of comets 1800-1899 (Cambridge: University Press), p. 268

Olson, R. J. M. \& Pasachoff, J. M. 1998, Fire in the Sky (Oxford: University Press), p. 227

Pasachoff, J. M., Olson, R. J. M., \& Hazen, M. L. 1996, J. Hist. Astron., 27, 129

Ray, M. 2002, Notes \& Queries Roy. Soc., 49, 491

Verne, J. 1877, Hector Servadac, voyages et aventures à travers le monde solaire (Paris: Hachette)

Weiss, E. 1888, Bilderatlas der Sternenwelt (Stuttgart: Verlag Esslingen), p. 123 